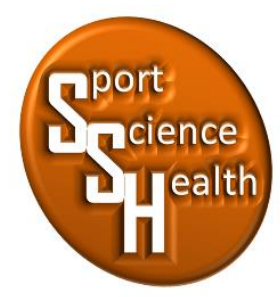

ISSN 2715-3886

\title{
Pengaruh Pemberian Sarung Tangan Kerja Terhadap Produktivitas pada Pekerja (Studi Kasus di Restoran)
}

\author{
Yudi Riza Firmansyah ${ }^{1 \star}$, Solichin ${ }^{2}$, Sendhi Tristanti Puspitasari ${ }^{3}$ \\ ${ }^{1,3}$ Jurusan IImu Kesehatan Masyarakat, Fakultas IImu Keolahragaan, Universitas Negeri Malang, \\ Jalan Semarang No 5, Malang, Jawa Timur, 65145, Indonesia \\ 2Jurusan Teknik Mesin, Fakultas Teknik, Universitas Negeri Malang, Jalan Semarang No 5, Malang, \\ Jawa Timur, 65145, Indonesia \\ *Penulis koresponden: yudi.rza@gmail.com, 081333784937
}

Artikel diterima: 11 Maret 2020; direvisi: 18 November 2020; disetujui: 23 November 2020

\begin{abstract}
Regional labor productivity, in 2015 showed that labor productivity in East Java Province was still below the national figure (68.74 million). The purpose of this study was to determine the effect of using work gloves on the productivity of workers in Restaurant X Malang City. The research design was included in experimental using a quasi-experimental model with a cross sectional approach. The results of the calculation of the Paired Sample Ttest data Pre-test and Post-test show that the sig. equal to 0.000 less than a equal to 0.05 . The conclusion that can be drawn is that there is an effect of working gloves on the productivity level of workers in Restaurant X Malang City.
\end{abstract}

Keyword: work gloves, productivity, crab

\begin{abstract}
Abstrak: Produktivitas tenaga kerja secara regional, pada tahun 2015 menunjukkan produktivitas tenaga kerja di Provinsi Jawa Timur masih di bawah angka nasional (68,74 juta). Tujuan penelitian ini untuk mengetahui pengaruh pemakaian Sarung Tangan Kerja terhadap produktivitas para pekerja di Restoran X Kota Malang. Rancangan penelitian termasuk dalam eksperimental menggunakan model eksperimen semu dengan pendekatan Cross Sectional. Hasil perhitungan uji Paired Sample T-test data Pre-test dan Post-test menunjukan bahwa nilai sig. sama dengan 0,000 kurang dari a sama dengan 0,05. Kesimpulan yang dapat diambil adalah ada pengaruh pemberian Sarung Tangan Kerja terhadap tingkat produktivitas pekerja di Restoran X Kota Malang.
\end{abstract}

Kata kunci: sarung tangan kerja, produktivitas, kepiting

\section{PENDAHULUAN}

Pada tahun 2015, tiga provinsi dengan jumlah tenaga kerja terbanyak yaitu provinsi Jawa Timur (19,37 juta orang), Jawa Barat (18,79 juta orang), dan Jawa Tengah (16,44 juta orang). Namun, pendidikan terakhir yang diselesaikan oleh tenaga kerja di provinsi tersebut sebagian besar (lebih dari 61 persen) adalah SMP kebawah. Provinsi Jawa Timur 67,63 persen berpendidikan SMP ke bawah, merupakan pendidikan terakhir yang ditempuh, untuk provinsi Jawa Barat dan Jawa Tengah sebesar 61,72 persen dan 71,59 persen. Selain memiliki jumlah tenaga kerja terbanyak di Indonesia, Jawa Timur juga memiliki PDRB yang tinggi, bahkan menempati urutan kedua (1331,42 trilliun). Akibatnya produktivitas tenaga kerja di Provinsi Jawa Timur masih 
di bawah angka nasional (68,74 juta). Hampir 37 persennya (7,08 juta orang) tenaga kerja di Jawa Timur tercatat bekerja pada sektor pertanian, kehutanan, dan perikanan atau kategori A (Kementrian Ketenagakerjaan \& BPS, 2016).

Kebutuhan akan rasa aman pada saat bekerja termasuk pemenuhan di bidang Keselamatan dan Kesehatan Kerja (K3) yang diberikan oleh perusahaan terhadap karyawannya, hal tersebut dikarenakan itu merupakan salah satu dari beberapa faktor yang akan mempengaruhi produktivitas kerja. Dalam meningkatkan produktivitas kerja, sulit tercapai apabila pada proses kerjanya terjadi suatu kecelakaan kerja yang dapat mengakibatkan penurunan kualitas maupun mengganggu proses produksi yang berdampak pada kapasitas produksi yang tidak tercapai sesuai harapan. Maka, K3 sangat berperan penting dalam menjaga keselamatan maupun keamanan pada proses produksi sehingga harapan dalam meningkatkan produktivitas dapat tercapai (Hidayati, 2016).

Kecelakaan kerja di Indonesia pada tahun 2011 tercatat mencapai angka 99.491 kasus. Jumlah tersebut terlihat meningkat jika dibandingkan dengan tahun 2010. Tahun 2007 terdapat 83.714 kasus, tahun 2008 tercatat 94.736 kasus, untuk tahun 2009 sebanyak 96.314 kasus, dan pada tahun 2010 terdapat 98.711 kasus. Negara Indonesia tergolong memiliki angka kecelakaan kerja yang tinggi. Lemahnya kedisiplinan dari para masyarakat ini menyebabkan angka tersebut masih tinggi. Alat pelindung diri merupakan hal wajib digunakan, di Indonesia terdapat 60 persen pekerja cedera kepala dikarenakan tidak menggunakan helm, 90 persen pekerja cedera pada wajah karena tidak menggunakan alat pelindung wajah, 77 persen pekerja cedera kaki karena tidak menggunakan sepatu pengaman, dan 66 persen pekerja cedera mata akibat tidak menggunakan alat pelindung mata (Jamsostek, 2012).

Solusi yang diberikan pemerintah berupa peraturan yang mengatur penggunaan alat pelindung diri yaitu pada Permenakertrans No. 1 Tahun 1981 pasal 5 ayat 2 menyatakan pekerja yang akan bekerja wajib memakai alat pelindung diri yang diperlukan sesuai risiko kerjanya untuk mencegah penyakit akibat kerja, peraturan ini dibuat dengan tujuan untuk melindungi pekerja itu sendiri dari bahaya yang ada di tempat kerja dan meningkatkan keselamatan dan kesehatan kerja pada saat menggunakan alat pelindung diri sehingga produktivitas dapat meningkat, menciptakan rasa aman dan terlindungi ketika bekerja, mampu meningkatkan motivasi untuk terus berkembang pada dunia kerja (Permenakertrans No. 8, 2010).

Berdasarkan hasil survei pendahuluan yang dilakukan peneliti di Restoran X Kota Malang pada bulan Juni 2019, produktivitas para pekerja di restoran tersebut masih belum maksimal. Pernyataan ini didapatkan dari jumlah kepiting yang dibersihkan oleh para pekerja masih di bawah target yang diberikan oleh perusahaan. Target yang diberikan perusahaan untuk membersihkan kepiting yaitu perorang mampu membersihkan kepiting minimal sebanyak $5 \mathrm{~kg}$ dalam waktu satu jam. Berdasarkan hasil observasi dan wawancara yang dilakukan, 28 pekerja dari 30 pekerja pada saat membersihkan kepiting tidak menggunakan Alat Pelindung Diri (APD) berupa sarung tangan, sedangkan 2 pekerja diantaranya menggunakan APD berupa sarung tangan katun yang kondisinya sudah hampir rusak. Kepiting yang dibersihkan terdapat duri pada cangkangnya. Proses pembersihan tanpa menggunakan APD ini bisa menyebabkan telapak tangan terluka akibat terkena duri dari cangkangnya sehingga meningkatkan angka kecelakaan kerja yang terjadi dan meningkatkan angka jam kerja yang hilang pada proses pembersihan kepiting. Pengamatan yang dilakukan terlihat bahwa tangan para pekerja banyak yang terluka dan mereka merasa kesakitan apabila telapak tangannya terkena air dan pekerja memaksakan tetap membersihkan kepiting.

Berdasarkan permasalahan APD peneliti mengajukan penggunaan sarung tangan kerja pada saat proses pembersihan kepiting yang berupa cut resistant gloves, sarung tangan katun dan sarung tangan kulit. Sarung tangan kerja yang digunakan ditujukan untuk melindungi para pekerja dari risiko bahaya pada saat membersihkan kepiting dan apakah dapat memberikan pengaruh terhadap produktivitas para pekerja dalam membersihkan kepiting, baik itu meningkatkan maupun menurunkan produktivitas. Seberapa bagus dari kualitas beberapa jenis sarung tangan kerja tersebut perlu dilakukan penelitian lebih lanjut.

\section{METODE}

Rancangan penelitian termasuk dalam eksperimental, dengan maksud untuk mengetahui perbedaan antara variabel sebab dan akibat. Penelitian eksperimen adalah mengadakan perubahan pada satu atau lebih variabel dan mempelajari pengaruhnya, yaitu perubahan yang terjadi pada variabel lainnya. Variabel yang 
dapat dimanipulasi disebut dengan variabel bebas atau variabel sebab, sedangkan untuk variabel lain yang dipengaruhi oleh variabel bebas biasa disebut dengan variabel tergantung atau variabel akibat. Manipulasi, artinya variabel tersebut dapat diubah-ubah sesuai dengan masalah yang diteliti.

Penelitian ini menggunakan desain dengan model eksperimen semu (quasi experimental design) dan model faktorial $3 \times 1$ yang melibatkan tiga kelompok responden yang bertujuan untuk membedakan pengaruh variabel bebas dan terikat. Variabel bebas pada penelitian ini adalah pemberian sarung tangan kerja (cut resistant gloves, sarung tangan katun dan sarung tangan kulit), sedangkan variabel terikat adalah produktivitas pekerja. Ketiga kelompok tersebut diasumsikan sama.

Dalam penelitian ini digunakan pendekatan Cross Sectional di mana penelitian dilaksanakan dengan observasi atau pengumpulan data hanya satu periode waktu dengan melakukan intervensi terhadap subjek penelitian. Berikut merupakan gambaran model penelitian yang digunakan:

Tabel 1. Gambaran Penelitian

\begin{tabular}{lllll}
\hline No & Variabel & Pretest & Perlakuan $(\mathbf{Y})$ & Posttest \\
\hline 1 & $X_{1}$ & $0_{1}$ & Cut Resistant Gloves & $0_{2}$ \\
2 & $X_{2}$ & $0_{1}$ & Sarung Tangan Katun & $0_{2}$ \\
3 & $X_{3}$ & $0_{1}$ & Sarung Tangan Kulit & $0_{2}$ \\
\hline
\end{tabular}

\section{Keterangan:}

$\mathrm{X}_{1} \quad$ : Variabel Perilaku

$\mathrm{X}_{2} \quad$ : Variabel Perilaku

$\mathrm{X}_{3} \quad$ : Variabel Perilaku

Y : Variabel Perlakuan

$0_{1} \quad$ : Test Awal (Pretest)

$\mathrm{O}_{2} \quad$ : Test Akhir (Posttest)

Penelitian ini dilakukan pada 30 Pekerja bagian dapur yang membersihkan kepiting di Restoran X Kota Malang, dari 30 pekerja dilakukan pembagian menjadi 3 kelompok dengan satu kelompok yang terdiri dari 10 orang. Kelompok 1 diberikan perlakuan pemakaian Cut Resistant Gloves, kelompok 2 diberikan perlakuan berupa pemakaian Sarung Tangan Katun dan kelompok 3 diberikan perlakuan dengan pemakaian Sarung Tangan Kulit. Sebelum diberikan intervensi, dilakukan pengambilan data awal berupa Pretest pada seluruh kelompok. Pretest dilakukan untuk melihat kondisi awal sama atau tidak, apabila memang sama penelitian dapat dilanjutkan setelah itu diberikan perlakuan dan dilakukan Posttest untuk melihat hasilnya. Setelah itu dari hasil Posttest dilakukan perbandingan antara kelompok 1 dengan kelompok 2, kelompok 1 dengan kelompok 3 dan kelompok 2 dengan 3.

Instrumen penelitian ini menggunakan metode observasi serta dokumentasi, untuk pengumpulan data menggunakan pengukuran berupa Stopwatch Digital untuk mengukur ketepatan waktu kerja dan pengukuran kuantitas kepiting bersih menggunakan Neraca Dapur Digital sehingga didapatkan produktivitas para pekerja pembersih kepiting di Restoran X.

Pengumpulan data penelitian ini dimulai pada fase pertama dimana pekerja membersihkan kepiting, setelah itu dilakukan penghitungan jumlah kepiting dalam satuan kilogram $(\mathrm{kg})$ yang dibersihkan oleh para pekerja dalam kurun waktu satu jam.

Pengukuran produktivitas dilakukan sebelum (Pretest) dan sesudah (Posttest) perlakuan. Cara yang digunakan untuk menghitung produktivitas pembersihan Kepiting para pekerja adalah dengan menggunakan rumus sebagai berikut (Sinungan, 2009:25):

$$
\text { P sama dengan } \frac{H}{T}(1)
$$

\section{Keterangan:}

P sama dengan Produktivitas Pembersihan Kepiting

$\mathrm{H}$ sama dengan Hasil Kerja $(\mathrm{kg})$

T sama dengan Waktu Kerja selama Pengamatan (jam) 
Analisis data yang digunakan adalah uji statistik parametrik, dengan metode yang digunakan adalah ANOVA (One Way).

\section{HASIL}

Restoran X merupakan restoran yang menjual makanan dengan bahan baku kebanyakan dari laut. Bahan baku utma yang digunakan Restoran $\mathrm{X}$ adalah kepiting dengan berbagai ukuran mulai yang terkecil dengan ukuran $160 \mathrm{gr}$ /ekor hingga yang paling besar yaitu 500gr/ekor bahkan bisa mencapai $800 \mathrm{gr} /$ ekor tergantung suplai yang didapat dari penyuplai bahan baku kepiting. Proses pembersihan bahan baku kepiting ini melewati beberapa tahap, dimulai dengan meletakkan kepiting yang akan dibersihkan pada tempat pembersihan kepiting yang ada di dapur, lalu membuka dan membersihkan tali rafia yang mengikat kepiting, setelah itu melepaskan cangkang kepiting dari badannya dan membersihkan kotoran pada seluruh badan kepiting.

\section{Hasil Produktivitas Pekerja Cut Resistant Gloves di Restoran X Kota Malang Tahun 2019}

Berikut adalah tabel gambaran hasil Produktivitas yang dilakukan pada kelompok 1 pekerja restoran $\mathrm{X}$ yang menggunakan Cut Resistant Glove pada saat membersihkan Kepiting selama satu jam.

Tabel 2. Hasil Produktivitas Pekerja Cut Resistant Gloves di Restoran X Kota Malang Tahun 2019

\begin{tabular}{ccc}
\hline \multicolumn{3}{c}{ KELOMPOK 1 } \\
\hline NO & $\mathrm{JK}$ & $\mathrm{Kg}$ \\
\hline 1 & $\mathrm{~L}$ & 7.23 \\
2 & $\mathrm{P}$ & 6.44 \\
3 & $\mathrm{P}$ & 6.54 \\
4 & $\mathrm{~L}$ & 7.12 \\
5 & $\mathrm{~L}$ & 7.15 \\
6 & $\mathrm{~L}$ & 6.97 \\
7 & $\mathrm{~L}$ & 7.22 \\
8 & $\mathrm{~L}$ & 6.67 \\
9 & $\mathrm{~L}$ & 6.87 \\
10 & $\mathrm{~L}$ & 7.34 \\
\hline
\end{tabular}

Berdasarkan tabel 2 dapat diketahui bahwa tingkat produksi pada kelompok 1 didapatkan hasil rata-rata produksi sebesar $6,955 \mathrm{~kg} / \mathrm{jam}$, sedangkan hasil produksi paling tinggi yaitu 7,34 kg/jam dan hasil produksi paling rendah yaitu sebesar 6,44 kg/jam.

\section{Hasil Produktivitas Pekerja Sarung Tangan Katun di Restoran X Kota Malang Tahun 2019}

Berikut adalah tabel gambaran hasil Produktivitas yang dilakukan pada kelompok 2 pekerja restoran $\mathrm{X}$ yang menggunakan Sarung Tangan Katun pada saat membersihkan Kepiting selama satu jam.

Tabel 3. Hasil Produktivitas Pekerja Sarung Tangan Katun di Restoran X Kota Malang Tahun 2019

\begin{tabular}{ccc}
\hline \multicolumn{3}{c}{ KELOMPOK 2 } \\
\hline NO & JK & Kg \\
\hline 1 & $\mathrm{~L}$ & 6.11 \\
2 & $\mathrm{~L}$ & 5.97 \\
3 & $\mathrm{~L}$ & 6.83 \\
4 & $\mathrm{~L}$ & 5.87 \\
5 & $\mathrm{~L}$ & 5.57 \\
6 & $\mathrm{P}$ & 5.23 \\
7 & $\mathrm{P}$ & 5.43 \\
8 & $\mathrm{~L}$ & 6.23 \\
9 & $\mathrm{~L}$ & 6.33 \\
10 & $\mathrm{~L}$ & 5.93 \\
\hline
\end{tabular}


Berdasarkan tabel 3 dapat diketahui bahwa tingkat produksi pada kelompok 2 didapatkan hasil rata-rata produksi sebesar $5,95 \mathrm{~kg} / \mathrm{jam}$, sedangkan hasil produksi paling tinggi yaitu $6,83 \mathrm{~kg} / \mathrm{jam}$ dan hasil produksi paling rendah yaitu sebesar $5,23 \mathrm{~kg} / \mathrm{jam}$.

\section{Hasil Produktivitas Pekerja Sarung Tangan Kulit di Restoran X Kota Malang Tahun 2019}

Berikut adalah tabel gambaran hasil Produktivitas yang dilakukan pada kelompok 3 pekerja restoran $X$ yang menggunakan Sarung Tangan Kulit pada saat membersihkan Kepiting selama satu jam.

Tabel 4 Hasil Produktivitas Pekerja Sarung Tangan Kulit di Restoran X Kota Malang Tahun 2019

\begin{tabular}{ccc}
\hline \multicolumn{3}{c}{ KELOMPOK 3 } \\
\hline NO & JK & Kg \\
\hline 1 & $\mathrm{~L}$ & 4.34 \\
2 & $\mathrm{~L}$ & 5.22 \\
3 & $\mathrm{~L}$ & 4.97 \\
4 & $\mathrm{P}$ & 5.78 \\
5 & $\mathrm{P}$ & 4.33 \\
6 & $\mathrm{~L}$ & 3.56 \\
7 & $\mathrm{~L}$ & 5.44 \\
8 & $\mathrm{~L}$ & 4.76 \\
9 & $\mathrm{~L}$ & 5.34 \\
10 & $\mathrm{~L}$ & 4.65 \\
\hline
\end{tabular}

Berdasarkan tabel 4 dapat diketahui bahwa tingkat produksi pada kelompok 3 didapatkan hasil rata-rata produksi sebesar $4,839 \mathrm{~kg} / \mathrm{jam}$, sedangkan hasil produksi paling tinggi yaitu $5,78 \mathrm{~kg} / \mathrm{jam}$ dan hasil produksi paling rendah yaitu sebesar $3,56 \mathrm{~kg} / \mathrm{jam}$.

\section{Hasil Analisis Pengaruh Pemberian Sarung Tangan Kerja terhadap Produktivitas pada Pekerja di Restoran X Kota Malang}

Adapun hasil uji paired sample T-test pada pekerja akan dijabarkan sebagai berikut:

Tabel 5 Hasil Uji Paired Sample T-test

\begin{tabular}{|c|c|c|c|c|c|c|}
\hline & & \multicolumn{2}{|c|}{$\begin{array}{c}\text { 95\% Confidence Interval of the } \\
\text { Difference }\end{array}$} & \multirow[t]{2}{*}{$\mathrm{t}$} & \multirow[t]{2}{*}{$d f$} & \multirow[t]{2}{*}{ Sig. (2-tailed) } \\
\hline & & Lower & Upper & & & \\
\hline Pair 1 & $\begin{array}{c}\text { Post-test-Pre- } \\
\text { test }\end{array}$ & 1.318698 & 1.903302 & 11.272 & 29 & .000 \\
\hline Pair 2 & $\begin{array}{l}\text { Pre-test-Post- } \\
\text { test }\end{array}$ & -1.903302 & -1.318698 & -11.272 & 29 & .000 \\
\hline
\end{tabular}

Hasil perhitungan uji Paired Sample T-test data Pre-test dan Post-test pada tabel 5 menunjukan bahwa nilai signifikansi sama dengan 0,000 kurang dari a sama dengan 0,05 . Kesimpulan yang dapat diambil adalah ada pengaruh pemberian Sarung Tangan Kerja terhadap tingkat produktivitas pekerja di Restoran X Kota Malang.

Adapun hasil uji multivariat data produktivitas pekerja pada saat menggunakan Sarung Tangan Kerja yang akan dijabarkan sebagai berikut:

Tabel 6 Hasil Uji Multivariat Data Produktivitas

\begin{tabular}{cccccc}
\hline \multicolumn{5}{c}{ Post-test } \\
\hline & Sum of Squares & Df & Mean Square & F & Sig. \\
\hline Between Groups & 22.406 & 2 & 11.203 & 45.183 & .000 \\
Within Groups & 6.695 & 27 & .248 & & \\
Total & 29.101 & 29 & & & \\
\hline
\end{tabular}


Hasil perhitungan uji ANOVA data produktivitas pekerja dengan Sarung Tangan Kerja pada tabel 6 menunjukan bahwa nilai signifikansi sama dengan 0,000 kurang dari a sama dengan 0,05 . Kesimpulan yang dapat diambil adalah ada perbedaan tingkat produktivitas kerja antara pekerja yang menggunakan Sarung Tangan Kerja yang satu dengan yang lainnya pada Restoran X di Kota Malang.

Mengetahui tingkat perbedaan setiap jenis Sarung Tangan Kerja yang diteliti maka dilakukan uji lanjutan atau Uji Post-hoct dengan metode LSD.

Tabel 7 Hasil Uji Post-hoct

\begin{tabular}{|c|c|c|c|c|c|}
\hline & \multirow{2}{*}{ (I) Kelompok } & \multirow{2}{*}{ (J) Kelompok } & \multirow{2}{*}{ Sig. } & \multicolumn{2}{|c|}{ 95\% Confidence Interval } \\
\hline & & & & Lower Bound & Upper Bound \\
\hline & Glove CRG & Glove Katun & .000 & .54809 & 1.46191 \\
\hline \multirow{2}{*}{ LSD } & & Glove Kulit & .000 & 1.65909 & 2.57291 \\
\hline & Glove Katun & Glove Kulit & .000 & .65409 & 1.56791 \\
\hline
\end{tabular}

Berdasarkan hasil uji Post-hoct pada tabel 7 bahwa nilai signifikansi sama dengan 0,000 kurang dari $\alpha$ sama dengan 0,05 . Kesimpulan pertama yang dapat diambil adalah ada perbedaan tingkat produktivitas kerja antara pekerja yang menggunakan Cut Resistant Glove dengan Sarung Tangan Katun pada pekerja di Restoran X Kota Malang. Kesimpulan kedua yang dapat diambil adalah ada perbedaan tingkat produktivitas kerja antara pekerja yang menggunakan Cut Resistant Glove dengan Sarung Tangan Kulit pada pekerja di Restoran X Kota Malang. Kesimpulan ketiga yang dapat diambil ada perbedaan tingkat produktivitas kerja antara pekerja yang menggunakan Sarung Tangan Katun dengan Sarung Tangan Kulit pada pekerja di Restoran X Kota Malang.

\section{PEMBAHASAN}

\section{Pengaruh Pemberian Sarung Tangan Kerja terhadap Produktivitas pada Pekerja di Restoran X Kota Malang}

Hasil analisis statistika menggunakan uji Paired Sample T-test data Pre-test dan Post-test menunjukan bahwa nilai signifikansi sama dengan 0,000 kurang dari a sama dengan 0,05 . Kesimpulan yang dapat diambil yaitu adanya perbedaan tingkat produktivitas kerja antara pekerja yang menggunakan Sarung Tangan Kerja dengan pekerja yang tidak menggunakan Sarung Tangan Kerja pada Restoran X di Kota Malang.

Berdasarkan penelitian dari Wati (2011) menyatakan adanya hubungan yang searah antara penggunaan alat pelindung diri terhadap produktivitas kerja para karyawan, yang dapat disimpulkan berupa semakin tingginya dalam hal penggunaan alat pelindung diri, maka produktivitas kerja para karyawan juga akan terus meningkat, hal ini juga berlaku sebaliknya.

Berdasarkan penelitian dari lkasari (2018) menyimpulkan bahwa terdapat pengaruh yang positif dan signifikan pada hubungan antara alat pelindung diri (APD) dan produktivitas karyawan. Perusahaan yang menyediakan alat pelindung diri sesuai untuk setiap karyawanini bisa menyebabkan karyawan akan merasa nyaman serta aman sehingga mampu meningkatkan tingkat produktivitas para karyawan itu sendiri.

Berdasarkan penelitian yang telah dilakukan oleh Sugarda (2014) didapatkan hasil bawha pekerja pertama (memakai APD sepatu safety, cattle pack, masker, kacamata dan helmet) menciptakan nilai yang paling baik di bandingkan pekerja kedua (memakai APD sepatu safety, cattle pack dan kacamata) maupun pekerja ketiga (memakai sepatu safety dan cattle pack). Waktu normal serta waktu standar yang paling baik nilainya adalah yang dihasilkan oleh pekerja pertama.

Berdasarkan penelitian dari Wardani (2013) menyatakan bahwa hasil analisis antara budaya K3 dengan produktivitas yang disimpulkan jika pekerja memiliki budaya K3 yang baik maka akan berimbas pada produktivitas mereka yang juga baik. Pernyataan tersebut diperkuat dengan analisis korelasi pearson yang menunjukkan nilai sig sama dengan 0.000kurang dari (a sama dengan 0,05) sehingga disimpulkan ada hubungan yang signifikan antara K3 dengan produktivitas kerja para pekerja, dengan semakin tingginya budaya K3 dari para pekerja maka semakin tinggi juga produktivitas para pekerja itu sendiri. 
Hasil penelitian dari Aprilliawan (2016) menyatakan bahwa hasil uji statistik yang dilakukan, maka dapat disimpulkan bahwa ada hubungan yang signifikan antara kepatuhan dalam menggunakan sarung tangan kain dengan kejadian kecelakaan kerja pada pekerja sub departemen preparation di PT. TKPI Temanggung. Hal ini didasarkan pada hasil uji alternatif yang mengunakan uji fisher dengan hasil $p$ value 0,018 kurang dari $(0,05)$. Kesimpulan dari data tersebut juga menunjukkan bahwa responden yang tidak patuh dalam menggunakan sarung tangan kain mempunyai kemungkinan sekitar 6,14 kali lebih berisiko mengalami kecelakaan kerja.

Penelitian dari Hidayah (2013) Mendapatkan hasil bahwa jika dibandingkan antara tahun 2009 dengan 2013 terdapat peningkatan produktivitas sebesar 15,41 persen yang diakibatkan pelaksanaan program penyediaan fasilitas dan sarana K3. Fasilitas tersebut berupa Klinik yang bisa digunakan oleh para pekerja, rest area yang tertata, koperasi, penyediaan kotak P3K yang bisa digunakan untuk pertolongan pertama dan penyediaan APD yang tepat guna.

Penelitian dari Choudhry \& Arabia (2018) menyatakan Lima faktor yang memberikan peningkatan maksimum dalam produktivitas dan keselamatan diidentifikasi dari uji-t, yaitu: koordinasi yang lebih baik antara kelompok kerja, peningkatan peralatan dan alat pelindung diri, hubungan pribadi yang lebih baik antara rekan kerja, situs kerja yang luas, dan penggunaan tenaga kerja yang lebih terampil.

\section{Perbedaan tingkat produktivitas pekerja yang menggunakan Cut Resistant Glove dan Sarung Tangan Katun}

Hasil analisis statistika dengan menggunakan uji Post-hoct menunjukkan bahwa nilai signifikansi sama dengan 0,000 kurang dari a sama dengan 0,05 . Kesimpulan yang dapat diambil yaitu ada perbedaan tingkat produktivitas kerja antara pekerja yang menggunakan Cut Resistant Glove dengan Sarung Tangan Katun pada pekerja bagian pembersih kepiting di Restoran X Kota Malang.

Hal tersebut sejalan dengan penelitian dari Ertekin \& Kirtay (2015) menyatakan indeks resistensi memotong dengan lima cara pada kain sampel, menunjukkan bahwa cut resistant glove memiliki ketahanan potong lima kali lebih baik daripada kain katun. Hal tersebut memberikan gambaran bahwa Cut Resistant Glove lebih baik dari pada sarung tangan katun dalam hal ketahanan terhadap sayatan pada saat bekerja dengan risiko bahaya sayatan sehingga meningkatkan keamanan para pengguna atau pekerja dalam hal bekerja, dan meningkatkan kecepatan atau akselerasi dalam pergerakan tangan yang mendukung pekerjaan lebih cepat selesai.

Penelitian dari Irzmańska (2012) mendapatkan hasil untuk sarung tangan dengan nitril para-aramide dengan indeks (I) (cut resistance of the material) berdasarkan PN-EN 388:2006 mendapatkan hasil sebesar 4.7 lebih besar dari pada sarung tangan katun yang hanya 1.3 ini berarti sarung tangan dengan nitril para-aramide lebih kuat dari potongan/sayatan dibandingkan sarung tangan katun yang mampu memberikan ketahanan dan keamanan pada saat bekerja.

Penelitian dari beberapa yang telah dilakukan menunjukkan nilai kekuatan yang lebih tinggi pada 0 dan 30 menit pada saat bekerja dari pada 90 dan 120 menit untuk tangan kosong, sarung tangan katun dan kondisi sarung tangan nilon, sedangkan tidak ada penurunan kekuatan cengkraman jari yang ditemukan antara awal dan akhir tugas saat memakai sarung tangan nitril sehingga daya cengkram cenderung stabil (Moore, Dunnill, \& Wilson, 2013; Pineles et al., 2017; Roghmann et al., 2015).

\section{Perbedaan tingkat produktivitas pekerja yang menggunakan Cut Resistant Glove dan Sarung Tangan Kulit}

Hasil analisis statistika dengan menggunakan uji Post-hoct menunjukkan bahwa nilai signifikansi sama dengan 0,000 kurang dari $\alpha$ sama dengan 0,05 . Kesimpulan yang dapat diambil yaitu ada perbedaan tingkat produktivitas kerja antara pekerja yang menggunakan Cut Resistant Glove dengan Sarung Tangan Kulit pada pekerja bagian pembersih kepiting di Restoran X Kota Malang.

Berdasarkan peneliatian Millard \& Vaughan (2015) hasil bahwa semakin besar ketebalan sarung tangan dan jumlah lapisan, semakin banyak tingkat kinerja ketangkasan manual terdegradasi. Sarung tangan anti potong dengan tingkat ketangkasan terburuk adalah kaku dan tidak fleksibel dan subjek mengalami masalah mengambil barang-barang kecil dan menekuknya tangan. Pekerjaan itu juga menyoroti faktor-faktor lain yang mempengaruhi kinerja ketangkasan manual, termasuk ukuran yang tepat, interaksi dengan pakaian lain yang dipakai saat itu, dan peralatan kerja yang digunakan. Kesimpulannya, ketika mengevaluasi sarung tangan 
untuk digunakan di tempat kerja, penting untuk menggunakan tes yang mencerminkan lingkungan kerja dan selalu mempertimbangkan keseimbangan antara perlindungan dan kegunaan dari sarung tangan tersebut.

\section{Perbedaan tingkat produktivitas pekerja yang menggunakan Sarung Tangan Katun dan Sarung Tangan Kulit}

Hasil analisis statistika dengan menggunakan uji Post-hoct bahwa nilai signifikansi sama dengan 0,000 kurang dari a sama dengan 0,05 . Kesimpulan yang dapat diambil yaitu ada perbedaan tingkat produktivitas kerja antara pekerja yang menggunakan Sarung Tangan Katun dengan Sarung Tangan Kulit pada pekerja bagian pembersih kepiting di Restoran X Kota Malang.

Hal tersebut sejalan dengan hasil penelitian dari Chen dalam Dianat, (2013) berdasarkan tes yang dilakukan pada sarung tangan katun (ukuran kecil, sedang dan besar), sarung tangan kulit yang lembut (ukuran kecil dan besar) dan sarung tangan kulit yang kasar (ukuran sedang dan besar). Menyatakan bahwa waktu yang dibutuhkan untuk menyelesaikan tugas perakitan dengan menggunakan sarung tangan kulit yang kasar dengan ukuran sedang lebih cepat dari pada menggunakan sarung tangan jenis lainnya.

Penelitian lainnya mengukur perlindungan yang diberikan oleh berbagai sarung tangan terhadap gigitan kelelawar dengan menggunakan indenters baja untuk mensimulasikan gigi dan mengukur kekuatan yang diperlukan untuk menusuk sarung tangan. Tingkat perlindungan yang diberikan oleh sarung tangan dibandingkan dengan kekuatan gigitan yang diharapkan dan ketajaman gigi kelelawar. Katun, kain sintetis berlapis plastik, dan bahan yang diiklankan sebagai tahan tusukan dan tahan gores mudah ditembus dibandingkan dengan sarung tangan kulit. Kulit Split memberikan tingkat perlindungan tertinggi, tetapi dengan ketangkasan yang lebih rendah. Ini paling baik untuk menangani kelelawar yang lebih besar. Kulit rusa memberikan perlindungan yang wajar tanpa banyak kerugian dalam ketangkasan untuk menangani kelelawar (Bingham et al., 2016; Blanco et al., 2017; Monaghan \& Hutchison, 2016; Montoya et al., 2013).

\section{KESIMPULAN}

Berdasarkan analisis data yang telah dilakukan oleh peneliti di Restoran X Kota Malang dapat disimpulkan bahwa terdapat pengaruh yang signifikan penggunaan Sarung Tangan Kerja terhadap produktivitas para pekerja di Restoran X Kota Malang. Terdapat perbedaan yang signifikan pada tingkat produktivitas kerja antara pekerja yang menggunakan Cut Resistant Gloves dengan pemakaian Sarung Tangan Katun terhadap tingkat produktivitas pekerja. Ada perbedaan yang signifikan pada tingkat produktivitas kerja antara pekerja yang menggunakan Cut Resistant Gloves dengan pemakaian Sarung Tangan Kulit terhadap tingkat produktivitas. Ada perbedaan yang signifikan pada tingkat produktivitas kerja antara pekerja yang menggunakan Sarung Tangan Katun dengan Sarung Tangan Kulit pada pekerja bagian pembersih kepiting di Restoran X Kota Malang.

\section{Ucapan Terima Kasih}

Penulis mengucapkan banyak terimakasih kepada banyak pihak yang telah membantu penyelesaian artikel ini. Penulis mengucapkan banyak terimakasih kepada Dr. Sapto Adi, M. Kes selaku dekan Fakultas IImu Keolahragaan Universitas Negeri Malang, drg. Rara Warih Gayatri, M. PH selaku ketua jurusan Kesehatan Masyarakat Universitas Negeri Malang, Drs. Solichin, S.T., M. Kes dan dr. Sendhi Tristanti P., M. Kes selaku pembimbing. Terimakasih kepada Restoran X Kota Malang sebagai tempat penelitian, tidak lupa juga kedua orang tua yang luar biasa dan telah memberikan dukungan moral mupun material dan mendoakan untuk kelancaran penelitian dan terselesainya artikel ini.

\section{DAFTAR PUSTAKA}

Aprilliawan. (2016). Kepatuhan Penggunaan Sarung Tangan Dengan Kecelakaan Kerja Di Perusahaan Dengan Kecelakaan Kerja Di Perusahaan Parquet Temanggung. 3(1), 1-10.

Bingham, J., Abell, G., Kienast, L. A., Lerner, L., Matuschek, B., Mullins, W., ... Kirk, J. (2016). Health care worker hand contamination at critical moments in outpatient care settings. American Journal of Infection Control. https://doi.org/10.1016/j.ajic.2016.04.208 
Blanco, N., Pineles, L., Lydecker, A. D., Johnson, J. K., Sorkin, J. D., Morgan, D. J., ... Lepcha, N. (2017). Transmission of resistant Gram-negative bacteria to health care worker gowns and gloves during care of nursing home residents in Veterans Affairs community living centers. Antimicrobial Agents and Chemotherapy. https://doi.org/10.1128/AAC.00790-17

Choudhry, R. M., \& Arabia, S. (2018). Achieving safety and productivity in construction projects. (September). https://doi.org/10.3846/13923730.2015.1068842

Dianat. (2013). Needlestick fluid transmission through surgical gloves of the same thickness. https://doi.org/10.1093/occmed/kqt135

Ertekin, M., \& Kirtay, H. E. (2015). Cut resistance of hybrid para-aramid fabrics for protective gloves. 5000(October). https://doi.org/10.1080/00405000.2015.1100820

Hidayah. (2013). Pelaksanaan Program Keselamatan dan Kesehatan Kerja dalam Meningkatkan Produktivitas Kerja Karyawan di PT. Tirta Investama Wonosobo.

Hidayati, D. (2016). Hubungan Antara Pemakaian Alat Pelindung Diri (Apd) Dengan Produktivitas Kerja Pada Pekerja Bagian Welding Di Pt. Barata Indonesia (Persero) Cabang Tegal. IImu Kesehatan Masyarakat.

Ikasari, N. (2018). Analisa Penerapan Alat Pelindung Diri ( APD) Terhadap Produktivitas. 3(1), 39-43.

Irzmańska, E. (2012). Comparative Evaluation of Test Methods for Cut Resistance of Protective Gloves According to Polish Standards. 5(94), 99-103.

Jamsostek. (2012). Laporan Tahunan 2012; Membangun Kekuatan Menuju BPJS Ketenagakerjaan. 42(3). https://doi.org/10.1111/epp.2606

Kementrian Ketenagakerjaan \& BPS. (2016). Pengukuran Produktivitas Nasional Regional.

Millard, C. E., \& Vaughan, N. P. (2015). Assessment of Protective Gloves for Use with Airfed Suits. 0, 1-12. https://doi.org/10.1093/annhyg/mev039

Monaghan, J. M., \& Hutchison, M. L. (2016). Ineffective hand washing and the contamination of carrots after using a field latrine. Letters in Applied Microbiology. https://doi.org/10.1111/lam.12549

Montoya, A., Chen, S., Galecki, A., McNamara, S., Lansing, B., \& Mody, L. (2013). Impact of health care worker policy awareness on hand hygiene and urinary catheter care in nursing homes: Results of a selfreported survey. American Journal of Infection Control. https://doi.org/10.1016/j.ajic.2012.09.024

Moore, G., Dunnill, C. W., \& Wilson, A. P. R. (2013). The effect of glove material upon the transfer of methicillinresistant Staphylococcus aureus to and from a gloved hand. American Journal of Infection Control. https://doi.org/10.1016/j.ajic.2012.03.017

Permenakertrans No. 8. (2010). Alat Pelindung Diri. Kemenakertrans, 1-69.

Pineles, L., Morgan, D. J., Lydecker, A., Johnson, J. K., Sorkin, J. D., Langenberg, P., ... Roghmann, M. C. (2017). Transmission of methicillin-resistant Staphylococcus aureus to health care worker gowns and gloves during care of residents in Veterans Affairs nursing homes. American Journal of Infection Control. https://doi.org/10.1016/j.ajic.2017.03.004

Roghmann, M. C., Johnson, K., Sorkin, J. D., Langenberg, P., Lydecker, A., Sorace, B., ... Mody, L. (2015). Transmission of methicillin-resistant staphylococcus aureus (Mrsa) to healthcare worker gowns and gloves during care of nursing home residents. Infection Control and Hospital Epidemiology. https://doi.org/10.1017/ice.2015.119

Sugarda, A., Santiasih, I., \& Juniani, A. I. (2014). Terhadap Allowance Proses Kerja Pemotongan Kayu ( Studi Kasus: PT . PAL Indonesia).

Wardani, R. (n.d.). Hubungan Budaya Kesehatandan Keselamatan Kerja (K3) Terhadap Produktivitas Kerja Di Bagian Instalasi PG.Mritjan Kediri.

Wati, L. N. (2011). Pengaruh Penggunaan Alat Pelindung Diri (APD) Terhadap Produktivitas Kerja Karyawan Pada PD Purnama, Cikarang. 1, 34-60. 